\title{
Physical benefits and reduction of depressive symptoms among the elderly: Results from the Portuguese "National Walking Program"
}

\author{
Benefícios físicos e redução de sintomas depressivos em idosos: \\ resultados do Programa Nacional de Caminhada Português
}

Jeronimo Costa Branco

Karen Jansen ${ }^{1}$

Jessica Teixeira Sobrinho ${ }^{2}$

Susana Carrapatoso ${ }^{3}$

Barbara Spessato ${ }^{1}$

Joana Carvalho ${ }^{3}$

Jorge Mota ${ }^{3}$

Ricardo Azevedo da Silva ${ }^{1}$
${ }^{1}$ Programa de PósGraduação em Saúde e Comportamento, Universidade Católica de Pelotas. R. Gonçalves Chaves 373/411, Centro. 96010-280 Pelotas RS Brasil. jeronimobranco@ hotmail.com

${ }^{2}$ Programa de PósGraduação em Psicologia, Instituto de Ciências Humanas. Universidade Federal de Juiz de Fora ${ }^{3}$ Centro de Investigação em Actividade Física, Saúde e Lazer, Universidade do Porto.
Abstract The aim of this study was to investigate alterations in physical fitness and anthropometric parameters as well as depression symptoms among the elderly after participation in the "National Walking Program" (Portugal). The sample consisted of 26 elderly people over six months with a total of 72 exercise sessions. The exercise sessions consisted of aerobics (walking and running) and strength and flexibility exercises. Participants were assessed pre- and post-intervention for physical fitness with the Rikli \& Jones test. The anthropometric measurements were assessed with a bioimpedance scale and a stadiometer, and depression with Yesavage's Geriatric Depression Scale. Physical activity was only assessed with an accelerometer at the pre-intervention phase. For statistical analysis, the student $t$ test for paired samples was performed using SPSS 21 software. Statistically significant improvements were found in depressive symptoms $(p \leq 0.001)$, and in all physical fitness tests $(p \leq 0.05)$ except for flexibility tests ( $p \geq 0.05)$. Waist circumference reduction also showed the positive effects of the intervention $(p=0.031)$. The conclusion drawn is that participation in the "National Walking Program" for 6 months was effective in improving the physical and psychological health of the elderly.

Key words The elderly, Exercises, Walking, Physical fitness, Depression
Resumo O objetivo do presente estudo foi verificar as alterações nos idosos após a participação no Programa Nacional de Marcha e Corrida de Portugal, em relação ao nível de aptidão física, medidas antropométricas, bem como os sintomas depressivos. Fizeram parte da amostra 26 idosos por um período de 6 meses com total de 72 aulas, que foram conduzidas com exercícios aeróbicos (marcha e corrida), de força e flexibilidade. Os dados de aptidão física foram mensurados pelo teste de Rikli \& Jones, os dados antropométricos através de balança de bioimpedância/estadiômetro e a depressão pela Escala de Depressão Geriatria de Yesavage, estas informações foram coletadas pré e pós-intervenção. O nível de atividade física foi avaliado por acelerômetro apenas na pré-intervenção. Para as análises estatísticas foi utilizado o programa SPSS através do teste t-Student para amostras pareadas. Encontramos uma melhora significativa no pré para o pós-teste nos sintomas depressivos $(p \leq 0.001)$ e em todos os testes de aptidão física $(p \leq 0.05)$, com exceção dos de flexibilidade ( $p \geq 0.05$ ). A redução da circunferência da cintura também demonstrou os efeitos positivos da intervenção ( $p=0.031)$. Podemos concluir que a participação no programa de Marcha e Corrida durante 6 meses foi eficaz na melhora da saúde física e psicológica do idoso.

Palavras-chave Idosos, Exercícios, Caminhada, Aptidão física, Depressão 


\section{Introduction}

The aging process, natural to life, includes changes in biopsychosocial aspects. Elderly people are more susceptible to the development of chronic health conditions such as cardiovascular diseases, cancers and depressive disorders ${ }^{1,2}$. Studies show that depressive disorders affect between $5 \%$ to over $30 \%{ }^{3,4}$ of older adults. The high prevalence of depression in elders is often related to loss of functionality, and physical fitness. Promoting physical fitness and maintaining functionality can be an important way to aid depression prevention of chronic conditions on older adults 5 .

Observational and experimental studies have demonstrated an inverse relationship between physical fitness and depressive symptoms $s^{6,7}$. The aging process is accompanied by inactivity, progressive loss of functionality ${ }^{2}$, and independence. Often the ability to perform daily life activities becomes restricted. Participations on physical activities that could help prevent functional loss by increasing physical fitness can be restricted due to age related physical constraints, thus developing a vicious cycle.

Also, physical activity can help improve health parameters: decreasing waist circumference, maintaining body mass index (BMI), normalizing body weight, maintaining bone mass, increasing strength and flexibility, and regulating lipid profile and glycemic control ${ }^{5}$. However, older adults have restricted opportunities to be physically active in order to prevent functional loss. Most opportunities are provided by gyms, however they can be held in alternative locations such as parks, at various times of the day in order to accommodate the elderly needs. Actually, simple activities such as walking and running can be very beneficial as long as they are systematic, progressive and planned ${ }^{2,8}$.

Walking and running are relatively low cost health promoting activities that can be performed as a group or individually9. With that in mind the "National Walking Program" in Portugal was developed. The program is innovative and wide-ranging, contributing to a better understanding of the logic-based health promotion walking intervention. The program was designed to contribute with improvements in elderly health through physical activities with qualified technical supervision. The present study investigated the effect of the "National Walking Program" (Portugal) in physical fitness, anthropometric measurements and depression symptoms of elderly participants.

\section{Material and Methods}

In this study, older adults aged 60 years or over were recruited to participate in the "National Walking Program" (NWP), which was conducted in the Centre of Physical Activity, Health and Leisure, Faculty of Sport, University of Porto, Porto, Portugal. All participants were recruited through advertisements in the local media. Participated on the study only subjects who were not engaged in regular physical activity, and were not on antidepressant medication. Written informed consent was obtained from all participants and research protocol was approved by the local Human Research Ethics Committee. All participants had their health status assessed by a physician, and the ones considered healthy to participate were included in the study. Also they had their health condition monitored during exercise by the physical therapist and physical education teacher. Vital signs and blood pressure were also verified in order to guarantee the participants safety. All subjects were evaluated at the beginning of NWP and 6 months after the intervention.

\section{NWP Walking \\ and running intervention protocol}

NWP sessions were performed 3 days/week during 6 months (72 exercise sessions in total). The sessions were instructed by a physical education staff member, ensuring adherence to the established walking protocol. All sessions comprised of a 10-minute warm-up, (calisthenics and stretching exercises), 20-30 minutes of walking at $50-75 \%$ HRReserve (Rating of Perceived Exertion - RPE of 4-6 on CR-10 scale) and 10 minutes cool-down (respiratory and flexibility exercises). Based on statement we used a gradual approach to increase training load over time until reach the target volume and intensity for walking program protocol ${ }^{10}$.

\section{Questionnaire}

Sociodemographic characteristics were assessed with a questionnaire investigating age, sex, years of study, income, and if they live with a partner. Also, we used Geriatric Depression Scale (GDS) by Yesavage, a 30-item self-report assessment used to identify depression symptoms in the elderly people as recommended by World Health Organization/CID-10. This instrument was developed and validated in two studies ${ }^{11}$ and it is currently one of the most used depression self-reports. The GDS is a questionnaire an- 
swered "yes" or "no" and a score $\geq 10$ is suggestive of depression. However this instrument was considered in a discrete scale for variation between 0 and 30 points.

\section{Physical Fitness}

The Functional Fitness Test $^{12}$ developed by Rikli e Jones ${ }^{13}$ that involves lower and upper body strength, aerobic endurance, lower and upper flexibility and motor agility through: "chair stand", "arm curl", "sit and reach", "back scratch", "up and go", "6-minute walk" were performed in order to evaluate the functional capacity.

Height, and body mass were measured by standardized procedures to calculate the body mass index $\left[\mathrm{BMI}=\right.$ weight $(\mathrm{Kg}) /$ height $\left.(\mathrm{m})^{2}\right]$. Body mass and percentage of body fat were measured simultaneously using Tanita MC 180 MA, a segmental multifrequency body composition monitor (Tanita Company, UK). The abdomen circumference was assessed at the midpoint between the iliac crest and the bottom of the ribcage using a spring-loaded measuring tape.

To measure habitual physical activity, all participants wore an accelerometer MTI Actigraph during seven days, at least 10 hours of using per day. The data were analysed with MAHUffe software using the count cutoffs for elderly people ${ }^{14}$ as follow: sedentary time (0-100 min), light activity time (101-1040 min), moderate (1041$2503 \mathrm{~min}$ ) and vigorous (more than $2540 \mathrm{~min}$ ). This information was collected only at baseline to associate the initial physical inactivity with depression symptoms.

\section{Statistical analyses}

Data were analyzed using the statistical program SPSS, v.20 (Chicago, IL, USA). Categorical variables were summarized as frequencies and percentages and continuous variables as means and standard deviation (SD). For comparisons between groups we used chi-square and student's $t$ test. To analyze differences in time we used paired- samples t-test. $P$ values $\leq 0.05$ were considered statistically significant.

\section{Results}

Initially, 30 older adults composed the study sample but only 26 completed the NWP, being 17 (65.4\%) women and 9 (34.6\%) men. Regarding sample characteristics we observed that 15 $(57.7 \%)$ live with a partner, the average of age was $65.5 \pm 4.75$ years, height was $1.59 \pm 0.81 \mathrm{~cm}$, years of schooling was $9.63 \pm 5.38$ years and income $1.092 \pm 832$ euros.

The frequency of depression before the intervention program was $30.8 \%$ with mean score of $8.03 \pm 5.17$. The habitual physical activity in the first week (before intervention) was 146.40 \pm 42.04 minutes of light activity, $52.22 \pm 21.96$ minutes of moderate activity and $33.59 \pm 20.65$ of vigorous activity. The older adults with depression symptoms showed lower physical activity levels than older adults with no depression symptoms as in moderate physical activity (39.57 \pm 14.37 vs. $58.13 \pm 22.70 ; \mathrm{p} \leq 0.032)$ and in vigorous physical activity $(19.57 \pm 22.72$ vs. $40.13 \pm$ 16.57; $\mathrm{p} \leq 0.026)$. However, no alterations were observed between older adults with and without depression symptoms in total minutes of light physical activity $(142.57 \pm 38.7$ vs. 148.20 $\pm 44.67 ; \mathrm{p} \leq 0.778)$ and sedentary time (599.28 \pm 152.98 vs. $563.00 \pm 58.06 ; \mathrm{p} \leq 0.563)$.

In fact we found no significant differences in regard to physical fitness at baseline and at post test between depressed and not depressed participants so the statistical analysis were conducted as one group. Table 1 shows the effects of NWP on anthropometric parameters, depression scale and physical fitness tests of all research participants. As we can see the intervention had effect on remission of depressive symptoms $(\mathrm{p} \leq 0.001)$

Table 1. Effects of "National Walking Program" on anthropometric parameters, depressive symptoms scale and physical fitness tests.

\begin{tabular}{lrrl}
\hline & Baseline & After & p value \\
\hline Depression & & & $\leq 0.215$ \\
$\quad$ No & $69.2 \%$ & $88.5 \%$ & \\
Yes & $30.8 \%$ & $11.5 \%$ & \\
GDS $^{*}$ & 8.03 & 5.00 & $\leq 0.001$ \\
Physical Fitness & & & \\
$\quad$ 6-minute walk (m) & 586.40 & 627.0 & $\leq 0.002$ \\
Arm Curl & 18.5 & 21.4 & $\leq 0.001$ \\
Chair stand & 20.2 & 22.6 & $\leq 0.010$ \\
Sit and reach (cm) & -3.7 & -1.6 & $\leq 0.195$ \\
Back scratch (cm) & -7.3 & -7.4 & $\leq 0.935$ \\
$\quad$ Up and go (s) & 4.7 & 4.3 & $\leq 0.001$ \\
Anthropometry & & & \\
$\quad$ Weight (Kg) & 70.49 & 72.46 & $\leq 0.287$ \\
Abdomen & 94.0 & 91.9 & $\leq 0.031$ \\
circumference (cm) & & & \\
\% of fat & 34.58 & 35.40 & $\leq 0.294$ \\
BMI & 27.27 & 27.93 & $\leq 0.278$ \\
\hline
\end{tabular}

"Geriatric Depression Scale - depressive symptoms - with score 30. ${ }^{*}$ Number of Repetitions. 
and in some physical fitness parameters such as 6-minute-walk ( $\mathrm{p} \leq 0.002)$, arm curl ( $\mathrm{p} \leq 0.001)$, chair stand ( $\mathrm{p} \leq 0.010)$, "up and go" ( $\mathrm{p} \leq 0.001)$, and the abdominal circumference significantly decreased of all research participants $(\mathrm{p} \leq 0.031)$.

There was no significant differences in frequency of depression ( $\mathrm{p}=0.215)$ from baseline $(30.8 \%)$ to post intervention $(11.5 \%)$. However, when we look at the depression symptoms average score we found a significant reduction form baseline (8.03 \pm 5.17$)$ and post intervention (5.0 $\pm 3.18)(\mathrm{p} \leq 0.001)($ Table 1$)$.

\section{Discussion}

Our findings showed that supervised "National Walking Program" in elderly people is able to attenuate physiological decline during aging as demonstrated by the increase physical fitness tests scores, decrease of abdominal circumference and mainly by the remission of depressive symptoms.

The prevalence of depression observed in our study was high $(30.8 \%)$, which is in line with other studies conducted in other countries. ${ }^{3,4,15-17}$. Some authors suggested that a decrease in mood in elderly people results in a depressive episode, mostly by the decline associated with aging such as: situations of continuous losses, decrease of familiar support and occupational status, and a continuous physical decline and diseases prevalence ${ }^{18}$.

Participation on the program decreased depressive symptoms. Similar results have been reported by other studies in regard to exercise-based interventions ${ }^{19,20}$. In fact, studies comparing different age groups, found that exercise-based intervention are more effective in reduction of depressive symptoms in this age group ${ }^{21,22}$. Additionally, exercise-based intervention is as effective in remission of depressive symptoms as drug intervention and psicotherapy ${ }^{20,23}$. Physical activity has the advantage of in addition to decreasing depressive symptoms to increase levels of physical health in elderly people.

Elders with depression spent less time in moderate and vigorous physical activity at the beginning of our study, like in other studies ${ }^{24,25}$. Physical activity was measured in a cross-sectional manner only at the beginning of the study. In a cross-sectional study we cannot identify the effect of causality of physical inactivity with depression, but it's association has been previously reported ${ }^{26}$. Nevertheless, longitudinal studies have shown that older adults that decrease intensity in physi- cal activity engagement ${ }^{26}$, and in physical fitness ${ }^{7}$ have more depressive symptoms compared to those who remain active throughout life ${ }^{26}$.

Physical fitness can act as a protective factor in the central nervous system, increasing survival, vascularization, neuronal stimulation and formation; ensuring an increase of neurotransmitters (serotonin, dopamine and norepinephrine) in the bloodstream, which during depression are dramatically reduced ${ }^{5,27}$. The neurologic changes contributes to the construction of individual's personality increasing the ability to deal with tensions and frustrations, and raises levels of self-esteem $^{28}$ through behavioral modeling ${ }^{29}$. Group socialization are also related to improvements in depressive symptoms promoting acquaintanceship, working as a support network, reaffirming personal identity, extending expressiveness, encouraging new friendships and fostering self-development to overcome the anxiety, uncertainty and insecurities ${ }^{30}$.

Our intervention design consisted of walking group sessions supervised by certified physical education professional. Studies comparing the effectiveness of physical exercise intervention showed that the benefits are more expressive when supervised ${ }^{31}$. The sessions consisted of strength and flexibility exercises, and most importantly of an aerobic exercise: walking. This being one of the physical activities largely available to the population to become physically active, especially because it does not demand the use of special equipment and presents little risk of injury ${ }^{8,9,32}$. The literature reports that walking is predominantly performed outdoors ${ }^{31}$ and although walking as physical-exercise is still scarcely practiced ${ }^{9}$.

Regarding physical fitness tests, we assessed flexibility, strength, resistance, mobility, dynamic balance, aerobic resistance before and after 6 months of the intervention. After the intervention, the older adults showed improvements in physical fitness tests. However, both flexibility tests demonstrated that the intervention was not able to overcome the passive tension and stiffness of skeletal muscles, significantly. The program did not focus on improving flexibility and little time was dedicated to stretching; also back pain $^{2}$ frequently reported by the elderly possibly limited the execution of movement required by the test. However, preserving mobility is in fact an indication of health improvement, since the elasticity of tendons, ligaments and joint capsules decrease over the years due to collagen decline, causing a decrease $8-10 \mathrm{~cm}$ of flexibility in the lower back and hip ${ }^{33}$. 
In the literature, it has been reported that strength decrease $15 \%$, between sixth and seventh decades of age, a similar age to our study sample ${ }^{34}$. Indeed, the participants not only maintained their physical fitness levels but also showed significant gains in muscle strength, which aids the performance of daily activities.

Aerobic test (6-minute test) showed significant improvement as a result of the walking intervention. Even if not measured directly, we highlight that the intervention was able to improve cardiovascular and respiratory capacity. Other studies showed that exercise increases aerobic power $10-40 \%$, especially by increasing the arteriovenous oxygen difference, stroke volume, cardiac output, plasma volume and blood ${ }^{35}$.

The intervention was not able to change significantly fat percentage and body weight. On the other hand, abdominal circumference, one of the most important aspects of cardiovascular health related to central obesity ${ }^{36-38}$, decreased significantly. Other studies showed benefits of exercise programs for physical health of the elderly, as an important prophylactic measure to delay the loss of natural physiological flexibility, strength, physical fitness and anthropometric measurements with advancing age $e^{2,20,33,39,40}$.

However our study breaks new ground because investigates the impact of a national initiative, based on a walking program focused on health, relatively easy to implement, and rarely reported in the literature.

One of the limitations is the lack of a control group to compare the results of the intervention. Also the small number of elderly participants, it is possible that with a larger sample size the associations tested would have greater statistical power. Our focus was on physical fitness and not on physical activity levels.

Due to that we measured physical activity only before the intervention started to establish physical activity levels and differences between depressed and not depressed participants. We believe future studies should also assess physical activity levels after the intervention in order to investigate possible behavioral changes related to physical activity engagement. Some strengths of our study refers to the assessment of an intervention based on an innovative program at the national walking, allowing through repeated measurements establish the benefits to physical and psychological health of the elderly. The intervention was guided by physical educators and assisted by a physical therapist to aid with injuries prevention.

The present results are important to inform the elderly population and the scientific community about the benefits of a walking program for seniors. The walking program here presented is an effective, feasible, preventive strategy. The program is cost effective and can contribute to public health system improvement by minimizing social and health care costs. Also, as a social policy, the intervention is effective in creating opportunities for physical activity engagement with gender and age equality.

Lifestyle changes with inclusion of exercises and reduction of sedentary behaviors contributes to effectively minimize risk factors for chronic diseases. This study found improvements in the overall health of the elderly including a reduction of depressive symptoms and anthropometric measures as was as an increase in physical fitness after 6 months of walking program.

\section{Collaborations}

JC Branco participated in the execution of the research, drafting and revision of article. $\mathrm{K}$ Jansen and B Spessato participated in the revision of the article. JT Sobrinho and S Carrapatoso participated in the execution of the research. J Carvalho participated in the execution of the research and drafting of the article. J Mota supervised the research and revised the article. RA Silva supervised the research and revised the article. 


\section{References}

1. Reichert CL, Diogo CL, Vieira JL, Dalacorte RR. Physical activity and depressive symptoms in community-dwelling elders from southern Brazil. Rev Bras Psiquiatr 2011; 33(2):165-170.

2. Alves RS, Mota J, Costa MC, Alves JGB. Aptidão física relacionada à saúde de idosos: influência da hidroginástica. Rev Bras Med Esporte 2004; 10(1):31-37.

3. Pinho MX, Custódio O, Makdisse M. Incidência de depressão e fatores associados em idosos residentes na comunidade: revisão de literatura. Rev Bras Geriatr Gerontol 2009; 12(1):123-140.

4. Silva E, Paniz V, Laste G, Torres I. Prevalência de morbidades e sintomas em idosos: um estudo comparativo entre zonas rural e urbana. Cien Saude Colet 2013; 18(4):1029-1040.

5. Nóbrega ACL, Freitas EV, Oliveira MAB, Leitão MB, Lazzoli JK, Nahas RM, Baptista CAS, Drummond FA, Rezende L, Pereira J, Pinto M, Randominski RB, Leite N, Thiele ES, Hernandez AJ, Araújo CGS, Teixeira JAC Carvalho T, Borges SF, De Rose EH. Posicionamento oficial da Sociedade Brasileira de Medicina do Esporte e da Sociedade Brasileira de Geriatria e Gerontologia: atividade física e saúde no idoso. Rev Bras Med Esporte 1999; 5(6):207-211.

6. Yamagata E, Yamada Y, Sugihara Y, Komatsu M, Kimura M, Okayama Y. Physical fitness and depression symptoms in community-dwelling elderly women. Nihon Koshu Eisei Zasshi 2013; 60(4):231-240.

7. Choi YH, Lee CJ. Effects of a recreational combination gymnastics program for old-old women. J Korean Acad Nurs 2012; 42(6):843-852.

8. Collet C, Chiaradia BM, Reis RS, Nascimento JV. Fatores determinantes para a realização de atividades físicas em parque urbano de Florianópolis. Rev Bras Ativ Fís Saúde 2008; 13(1):15-23.

9. Adamoli AN, Silva MC, Azevedo MR. Prática da caminhada no lazer na população adulta de Pelotas, RS. Rev Bras Ativ Fís Saúde 2011; 16(2):113-119.

10. Wanderley FAC, Oliveira J, Mota J, Carvalho J. Effects of a moderate-intensity walking program on blood pressure, body composition and functional fitness in older women: results of a pilot study. Arch Exerc Health Dis 2010; 1(2):50-57.

11. Montorio I, Izal M. The geriatric depression scale: a review of its development and utility. Int Psychogeriatr 1996; 8(1):103-112.

12. Rikli RE, Jones CJ. Reliability, validility, and methodological issues in assessing physical activity in older adults. Res Q Exerc Sport 2000; 71(Supl. 2):S89-96.

13. Rikli RE, Jones CJ. Development and validation of a functional fitness test for community-residing older adults. JAPA 1999; 7(2):129-161.

14. Copeland JL, Esliger DW. Accelerometer assessment of physical activity in active, healthy older adults. JAPA 2009; 17(1):17-30.
15. Bhamani MA, Karim MS, Khan MM. Depression in the elderly in Karachi, Pakistan: a cross sectional study. BMC Psychiatry 2013; 13(1):181-188.

16. Volkert J, Schulz H, Härter M, Wlodarczyk O, Andreas $\mathrm{S}$. The prevalence of mental disorders in older people in Western countries - a meta-analysis. Ageing Res Rev 2013; 12(1):339-353.

17. Ferreira PCS, Tavares DMS. Prevalence and factors associated with the rates of depression among elderly residents in rural areas. Rev Esc Enferm 2013; 47(2):401407.

18. Garcia A, Passos A, Campo AT, Pinheiro E, Barroso F, Coutinho G. A depressão e o processo de envelhecimento. Ciênc e Cogn 2005; 7(1):111-121.

19. McKercher CM, Schmidt MD, Sanderson KA, Patton GC, Dwyer T, Venn AJ. Physical activity and depression in young adults. Am J Prev Med 2009; 36(2):161-164.

20. Blumenthal JA, Babyak MA, Moore KA, Craighead WE Herman S, Khatri P, Waugh R, Napolitano MA, Forman LM, Appelbaum M, Doraiswamy PM, Krishnan KR. Ef fects of exercise training on older patients with major depression. Arch Intern Med 1999; 159(19):2349-2356.

21. Hassmen P, Koivula N, Uutela A. Physical exercise and psychological well-being: a population study in Finland. Prev Med 2000; 30(1):17-25.

22. Fukukawa Y, Nakashima C, Tsuboi S, Kozakai R, Doyo W, Niino N, Ando F, Shimokata H. Age differences in the effect of physical activity on depressive symptoms. Psychol Aging 2004; 19(2):346-351.

23. Oliveira ACB. Estudo comparativo dos efeitos da atividade física com os da terapêutica medicamentosa em idosos com depressão maior [tese]. São Paulo (SP): Universidade de São Paulo; 2005.

24. Hollenberg M, Haight T, Tager IB. Depression decreases cardiorespiratory fitness in older women. J Clin Epidemiol 2003; 56(11):1111-1117.

25. Strawbridge WJ, Deleger S, Roberts RE, Kaplan GA. Physical activity reduces the risk of subsequent depression for older adults. Am J Epidemiol 2002; 156(4):328-334.

26. Lampinen P, Heikkinen RL, Ruoppila I. Changes in intensity of physical exercise as predictors of depressive symptoms among older adults: an eight-year follow-up. Prev Med 2000; 30(5):371-380.

27. Godoy RF. Benefícios do exercício físico sobre a área emocional. Rev Movimento 2002; 8(2):7-15.

28. Werneck, FZ, Bara Filho MG, Ribeiro LCS. Mecanismos de melhoria do humor após o exercício: Revisitando a hipótese das endorfinas. Rev Bra Ci e Mov 2005; 13(2):135-144

29. Guszkowska M. Effects of exercise on anxiety, depression and mood. Psychiatr Pol 2004; 38(4):611-620.

30. Garcia MAA, Yagi GH, Souza CS, Odoni APC, Frigério $\mathrm{RM}, \mathrm{Merlin}$ SS. Atenção à saúde em grupos sob a perspectiva dos idosos. Rev Latino-Am de Enfermagem 2006; 14(2):175-182. 
31. Rybarczyk B, DeMarco G, DeLaCruz M, Lapidos S. Comparing mind-body wellness interventions for older adults with chronic illness: classroom versus home instruction. Behav Med 1999; 24(4):181-190.

32. Eyler AA, Brownson RC, Bacak SJ, Housemann RA. The epidemiology of walking for physical activity in the United States. Med Sci Sports Exerc 2003; 35(9): 1529-1536.

33. Rebelatto JR, Calvo JI, Orejuela JR, Portillo JC. Influência de um programa de atividade física de longa duração sobre a força muscular manual e a flexibilidade corporal de mulheres idosas. Rev Bras Fisioter 2006; 10(1):127-132.

34. Harries JM, Bassey EJ. Torque- velocity relationship for the knee stensors en women in their 3th na 7rd decades. Eur J Appl Physiol 1990; 60(3):187-190.

35. Matsudo SM, Matsudo VKR, Barros Neto TL. Efeitos benéficos da atividade física na aptidão física e saúde mental durante o processo de envelhecimento. Rev Bras Ativ Fís Saúde 2000; 5(2):60-76.

36. Lemieux S, Prud'homme D, Bouchard C, Tremblay A, Després JP. A single threshold value of waist girth identifies normal-weight and overweight subjects with excess visceral adipose tissue. Am J Clin Nutr 1996; 64(5): 685-693.

37. Sarno F, Monteiro CA. Relative importance of body mass index and waist circumference for hypertension in adults. Rev Saude Publica 2007; 41(5):788-796.

38. Mota JF, Rinaldi AEM, Pereira AF, Orsatti FL, Burini RC. Indicadores antropométricos como marcadores de risco para anormalidades metabólicas. Cien Saude Colet 2011; 16(9):3901-3908.

39. Carvalho J, Soares JMC. Envelhecimento e força muscular - breve revisão. Rev Port Cien Desp 2004; 4(3):7993.

40. Sá ACAM, Bachion MM, Menezes RL. Exercício físico para prevenção de quedas: ensaio clínico com idosos institucionalizados em Goiânia, Brasil. Cien Saude Colet 2012; 17(8):2117-2127.

Artigo apresentado em 22/04/2014

Aprovado em 11/08/2014

Versão final apresentada em 13/08/2014 
